\title{
Thrombocytosis - a Valuable Parameter for Assessing Severity of Crohn's Disease Patients
}

\author{
Ana STEMATE', Teodora SPATARU', Delia NEGRU-VODÅ', Lucian NEGREANU'
}

\begin{abstract}
Background and aim: Capsule endoscopy is the most sensitive method for evaluating mucosal lesions in Crohn's disease and recent studies show that capsule endoscopy could be used for disease staging and for careful monitoring to evaluate endoscopic activity on a regular basis. Over time, many platelet changes have been described in IBD, including morphological and functional alteration and increased number. We determined whether platelets count correlates with the endoscopic activity measured using capsule endoscopy in Crohn's disease patients from a single center. Methods: This is a retrospective observational study. There were enrolled patients with suspected or known Crohn's disease that underwent evaluation with capsule endoscopy in our department, between 2011 and 2021. For the evaluation with capsule endoscopy, Pillcam SB3 or Pillcam Colon2 were used. For the evaluation of endoscopic activity, we used Lewis score calculated using RAPID 8 capsule-reading software. Platelets level was measured and correlated with the Lewis score, inflammatory biomarkers (C-reactive protein and fecal calprotectin) and anemic syndrome. Results: A total of 62 patients were included in the study, of whom 37 (59.67\%) were with suspected Crohn's disease and 25 (40.32\%) were with known Crohn's disease. Thrombocytosis was present in the majority of patients with severe endoscopic activity (Lewis score more than 790), elevated CRP, fecal calprotectin more than 250microg/g and anemic syndrome. Conclusion: To our knowledge, this is the first study that assess the correlation between thrombocytosis and severity of Crohn's disease, evaluated with capsule endoscopy. Our data suggests that platelet count is a valuable, non-invasive, easy to use biomarker that is a good predictor of severity of Crohn's disease and could have a prognostic value. It correlates well with Lewis score, CRP, fecal calprotectin and anemia.
\end{abstract}

Keywords: capsule endoscopy, inflammatory bowel disease, Crohn's disease, thrombocytosis, platelet count.

\section{Rezumat}

Introducere și obiectiv: Videocapsula endoscopică (VCE) reprezintă cea mai sensibilă metodă de evaluare a leziunilor mucosale la pacienții cu boală Crohn, iar studile recente demonstrează că aceasta ar putea fi folosită atât pentru stadializarea bolii cât și în monitorizarea strânsă a pacienților cu boală Crohn. De-a lungul timpului, la pacienții cu boli inflamatorii intestinale au fost descrise diverse modificări ale trombocitelor, constând în anomalii morfologice, funcționale cât și creșterea numărului acestora. În acest studiu am determinat relația dintre numărul plachetelor și activitatea endoscopică evaluată cu ajutorul capsulei endoscopice la pacienții cu boală Crohn investigați în cadrul unui centru terțiar de boli inflamatorii intestinale din România. Metode: Am realizat un studiu retrospectiv, observațional. Au fost incluși în studiu 62 de pacienți cu boală Crohn suspectată sau cunoscută, care au fost investigați cu ajutorul capsulei endoscopice în cadrul instituției noastre între 2011 și 2021. S-au folosit capsule Pillcam Colon2 sau Pillcam SB3. Inflamația intestinală a fost evaluată utilizând scorul Lewis calculat cu ajutorul softului RAPID 8. Numărul trombocitelor a fost măsurat și corelat cu scorul Lewis, biomarkeri inflamatori (proteina C reactivă și calprotectina fecală) și sindromul anemic. Rezultate: Au fost incluși în studiu 62 de pacienți,

\footnotetext{
' Department of Gastroenterology 2, Emergency University Hospital, „Carol Davila" University of Medicine and Pharmacy, Bucharest, Romania
}

\section{Corresponding author.}

Teodora SPATARU, Department of Gastroenterology 2, Emergency University Hospital, "Carol Davila" University of Medicine and Pharmacy,169 Splaiul Independentei, 5th District, Bucharest Romania. E-mail: spataru.teodora93@gmail.com 
dintre care 37 (59,67\%) cu suspiciune de boală Crohn iar 25 (40,32\%) cu boală Crohn cunoscută. Thrombocitoza a fost prezentă la un număr semnificativ de pacienți cu activitate endoscopică severă (scor Lewis mai mare de 790), sindrom inflamator, valori crescute ale calprotectinei fecale și anemie. Concluzii: Din revizuirea personală a literaturii de specialitate, nu există studii similare care să evalueze relația dintre trombocitoză și activitatea endoscopică a bolii Crohn stabilită secundar investigației cu VCE. Rezultatele acestui studiu susțin că valoarea trombocitelor poate fi un biomarker valoros, non-invaziv, ușor de utilizat, fiind un bun predictor al severității bolii la pacienții cu boală Crohn, acesta corelându-se pozitiv cu scorul Lewis, proteina C reactivă, fecală calprotectina fecală și anemia. Trombocitoza reprezintă factor prognostic al bolii, putând avea impact asupra evoluției și monitorizării bolii, cât și asupra conduitei terapeutice.

Cuvinte cheie: videocapsulă endoscopică, boală inflamatorie intestinală, boală Crohn, trombocitoză, numărul trombocitelor.

\section{INTRODUCTION}

Inflammatory bowel diseases (IBD) are chronic disorders of the digestive tract, with a cyclic evolution, with times of relapsing and remission, requiring lifelong monitoring and treatment. As the incidence and prevalence of IBD are increasing over time ${ }^{1,2}$, with a particular impact on the young population, affecting the quality of life of these patients and the healthcare system and economy in general, international studies have tried to optimize diagnostic, monitoring and therapeutic strategies.

Crohn's disease $(\mathrm{CD})$ can affect any segment of the digestive tract. Ileocolonoscopy with biopsies remains the golden standard for diagnosis of Crohn's disease but because of the inaccessibility of the small bowel to conventional endoscopy, capsule endoscopy is a valuable tool in monitoring and diagnosing Crohn's disease, assessing the mucosal inflammation, with the advantage that can evaluate the entire digestive tract. More than that, recent studies show that capsule endoscopy could be used for careful monitoring and could be incorporated in a "treat to target” approach for patients with Crohn's disease to evaluate endoscopic activity on a regular basis ${ }^{3}$.

The best method for monitoring Crohn's disease activity is still under question. There are many available biomarkers that can be used in clinical practice to evaluate the activity in Crohn's disease patients. C-reactive protein $(\mathrm{CRP})$ and fecal calprotectin $(\mathrm{FC})$ are the most used. CRP is a non-specific marker that has a good correlation with Crohn's disease clinical and endoscopic activity $^{4}$ and $\mathrm{FC}$ is more specific to intestinal inflammation, with better correlation with endoscopic activity in Crohn's disease ${ }^{5}$.
Over time, many platelet changes have been described in IBD, including morphological and functional alteration and increased number ${ }^{6}$. Platelets play an important role, beyond homeostasis and thrombosis in the inflammatory cascade in IBD. The first study that demonstrate correlation between thrombocytosis and IBD activity was done in 1968 and since then there were many studies trying to establish the role of platelet in IBD and the association of the increased number of platelets with clinical end endoscopic activity of IBD.

The aim of the present study is to determine whether platelets count correlates with the endoscopic activity measured using capsule endoscopy in Crohn's disease patients from a single center. This association between thrombocytosis and severity of Crohn's disease could make platelets count a valuable, easy to use, non-invasive biomarker for monitoring and assessing Crohn's disease severity.

\section{PATIENTS AND METHOD}

This is a retrospective observational study. There were enrolled patients with suspected (based on clinical and biochemical parameters) or known Crohn's disease. They underwent evaluation with capsule endoscopy in a tertiary IBD center from Bucharest, between 2011 and 2021. We reviewed electronic medical records and the results from the endoscopy department. For the evaluation with capsule endoscopy, Pillcam SB3 or Pillcam Colon2 were used, depending on their availability at the hospital at the moment of the investigation. The preparation for endoscopic videocapsule administration was similar to the preparation for colonoscopy, involving fasting for at least 12 hours and the administration of macrogol solution 12-16 hours prior to capsule 
ingestion (MOVIPREP). To improve the quality of the recorded images and to facilitate intestinal transit, a bolus of macrogol solution was administered 2 hours after the ingestion of the capsule.

In all patients, previously the examination with capsule endoscopy, a computed tomography enterography was done to rule out a significant stenosis.

Exclusion criteria: age $<18$; known significant stenosis or fistulas; swallowing disorders; pregnancy; other diseases that can explain the symptoms (vasculitis, lymphoma, intestinal infections), non-steroidal anti-inflammatory consumption in the last month prior to capsule endoscopy investigation; patients with cognitive impairment.

For the evaluation of endoscopic activity, we used Lewis score calculated using RAPID 8 capsule-reading software.

Platelets level was measured and correlated with the Lewis score, inflammatory biomarkers (C-reactive protein-CRP and fecal calprotectin) and anemic syndrome. Thrombocytosis was defined as a platelet count more than $450000 / \mathrm{mm} 3$. For the anemia we applied the World Health Organization definition according to which anemia is defined as hemoglobin level $<13 \mathrm{~g} / \mathrm{dl}$ in males and $<12 \mathrm{gdl}$ in nonpregnant females ${ }^{7}$. Elevated $\mathrm{CRP}$ was considered more than $5 \mathrm{mg} / \mathrm{dl}$ and the value more than $250 \mathrm{microg} / \mathrm{g}$ for fecal calprotectin was considered for active disease.

Statistical analysis was done using SPSS (Statistical Program for Social Sciences). In order to evaluate if there is any statistically significant correlation between the endoscopic activity and thrombocytosis, we used the Chi-squared test. Statistical significance was set at $\mathrm{p}<0.05$.

\section{RESULTS}

A total of 62 patients were included in the study, of whom 37 (59.67\%) were with suspected Crohn's disease and 25 (40.32\%) were with known Crohn's disease. Male to female ratio was 22/40. Patients age was between 20 and 67 years with mean age of 33 years $( \pm 14.43)$, with the predominance in the age group of 20-30 (56.5\%).

Mucosal healing (Lewis score $<135$ ) was present in $13(23.21 \%)$ of the patients, 22 (39.29\%) of the patients had mild inflammatory disease (Lewis score 135-790) and 27 (43.50\%) had moderate and severe inflammatory activity (Lewis score $>790$ ). Regarding the presence of thrombocytosis, we noticed that 37 patients
(59.67\%) associated elevated platelet count and only 25 patients $(40.33 \%)$ had platelet level inferior to 450000 platelets $/ \mathrm{mm} 3$.

In order to assess whether in the patients analyzed in this study there is a correlation between the presence of thrombocytosis (defined as more than 450000 platelets/mm3) and endoscopic activity of Crohn's disease, we divided the studied patients into two groups, namely group 1 totalizing patients with mild endoscopic activity (Lewis score between 135 and 790) and patients in endoscopic remission (Lewis score less than 135) and group 2 being comprised of patients with moderate and severe endoscopic activity (Lewis score more than 790). In group 2, thrombocytosis was present in a statistically significant $(p<0.001)$ number of patients, at 24 from 27 patients included in this group. In group 1 thrombocytosis was found in 13 out 35 patients (Figure 1).

\section{Prevalence of thrombocytosis depending on endoscopic activity (Lewis score)}

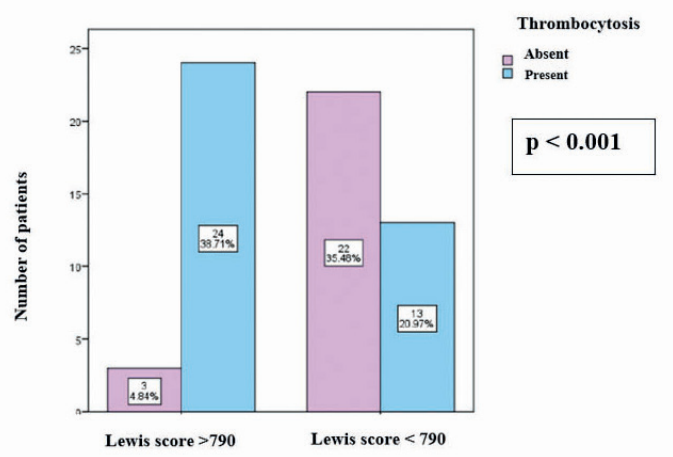

Figure 1. Prevalence of thrombocytosis depending on endoscopic activity (Lewis score)

In our study, we tried to determine if there is a correlation between platelet count and the other inflammatory biomarkers that are routinely used to assess the severity of Crohn's disease patients, like C-reactive protein, fecal calprotectin and hemoglobin value.

Anemia is a frequent complication in IBD patients. In our group we noticed an increased incidence of anemic syndrome, 50 patients of all 62 patients $(80.65 \%$ vs $19.35 \%, \mathrm{p}<0.001)$ associated low hemoglobin level before the examination with capsule endoscopy. A statistically significant ( $\mathrm{p}-0.004)$ percent of patients with anemia (54.84\% of all the patients) associated thrombocytosis (Figure 2). 


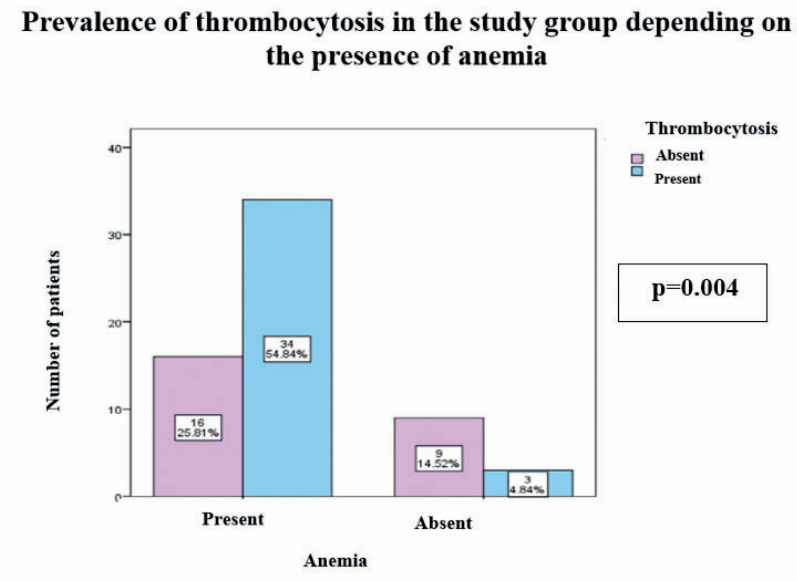

Figure 2. Prevalence of thrombocytosis in the study group depending on the presence of anemia

Prevalence of thrombocytosis depending on the value of fecal calprotectin

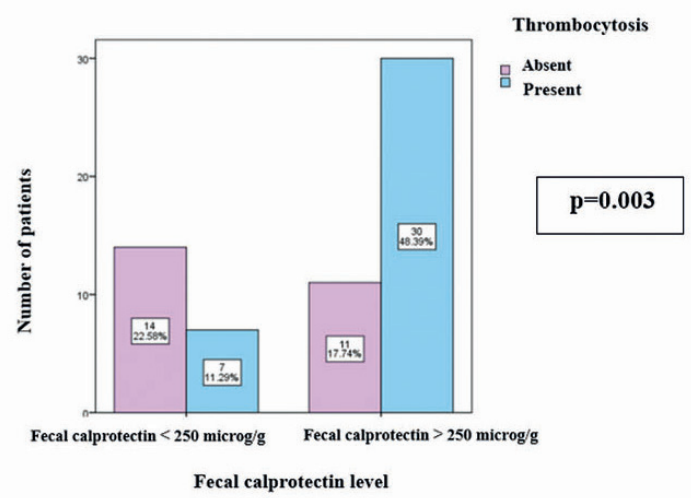

Figure 3. Prevalence of thrombocytosis depending on the value of fecal calprotectin

\section{Prevalence of thrombocytosis depending on the presence of} inflammatory syndrome

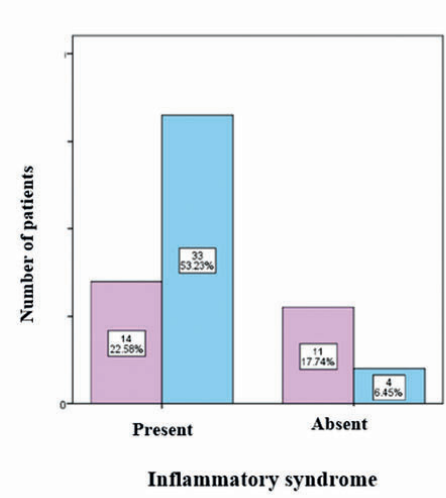

Thrombocytosis

品 $\begin{aligned} & \text { Absent } \\ & \text { Present }\end{aligned}$

$\mathrm{p}=\mathbf{0 . 0 0 4}$

Figure 4. Prevalence of thrombocytosis depending on the presence of inflammatory syndrome
Most patients enrolled in our study (75.81 \% vs $24.19 \%, \mathrm{p}<0.001)$ presented inflammatory syndrome defined as $\mathrm{CRP}>5 \mathrm{mg} / \mathrm{dl}$ and $41(66.13 \%)$ presented calprotectin levels superior to $250 \mathrm{microg} / \mathrm{g}$. Only 3 patients $(4.84 \%)$ had calprotectin levels inferior to $100 \mathrm{microg} / \mathrm{g}$. Because CRP and FC correlate with the activity of Crohn's disease, in order to evaluate if platelet count is increased when those inflammatory biomarkers have elevated values, we divided our patients in two groups, depending on their fecal calprotectin level. The first group included patients with fecal calprotectin values superior to $250 \mathrm{microg} / \mathrm{g}$ and the second group patients with lower values of fecal calprotectin. Platelet value more than 450000 platelet $/ \mathrm{ml}$ was encountered at statistically significant more patients from the first group versus the group with inferior level than $250 \mathrm{microg} / \mathrm{g}$ of fecal calprotectin ( $48.39 \%$ vs $11.29 \%$, $\mathrm{p}=0.003$ ) (Figure 3).

Also, in our study, thrombocytosis was associated with CRP more than $5 \mathrm{mg} / \mathrm{dl}$ at a statistically significant percent of patients compared with those with lower CRP (53,23\% vs 6,45\%, p=0.004) (Figure 4) .

Still, in our study group, we must acknowledge that there are 14 patients that have CRP level superior to $5 \mathrm{mg} / \mathrm{dl}$ and normal platelet count and 11 patients with fecal calprotectin superior to $250 \mathrm{microg} / \mathrm{g}$ that don't associate thrombocytosis.

\section{DISCUSSION}

Capsule endoscopy is a non-invasive and sensitive tool in evaluating the mucosal inflammation in Crohn's disease patients. Many platelet changes has been described in IBD, including morphological and functional alteration and increased number 6 .

We examined 62 patients and we aimed to determine if there is any correlation between thrombocytosis and endoscopic activity. Thrombocytosis was present in the majority patients $(\mathrm{p}<0.001)$ with severe endoscopic activity (Lewis score more than 790), namely at 24 from 27 patients included in this group. The first study that demonstrated correlation between thrombocytosis and IBD activity was done in 1968 by Morowitz et al. ${ }^{8}$. Subsequently, other studies tried to establish the relationship between platelet count and clinical or endoscopic activity of patients with IBD. In a study published by Li et al, including 137 patients with Crohn's disease, they demonstrated that clinical activity quantified using Crohn's disease Activity Index (CDAI) was positively correlated with platelet count ${ }^{5}$. The article of 
Holmquist et al, published in 1989 , provides a positive relationship between endoscopic activity and platelet count. They also showed that thrombocytosis was associated with severe and extensive colitis in CD patients with colon involvement, but also in ulcerative colitis ${ }^{10}$.

Because in our studied population there is a strong association between elevated platelet count and endoscopic severity, we consider that thrombocytosis could be a predictor of severity in CD patients and could have a prognostic impact with a role in monitoring and treatment optimization. The prognostic role of thrombocytosis in IBD is also confirmed by Okon et al, who showed that the incidence of chronic pouchitis was higher after total colectomy in UC patients presenting thrombocytosis preoperatively ${ }^{11}$, but this data is refuted by other researchers ${ }^{12}$. Thrombocytosis could also be a predictor of corticoid dependence or lack of response for some therapies in $\mathrm{IBD}^{13,14}$ and is also associated with the risk of thromboembolic events and coronary artery disease, common complications in IBD patients ${ }^{15}$. The role of thrombocytosis in monitoring $\mathrm{CD}$ patients is confirmed in a recent study, in which Silva et al. demonstrated that age younger than 30 years, platelet count more than $280000 / \mathrm{mm} 3$ and extraintestinal manifestations are associated with increased risk of relapse in the next year, in CD patients with mucosal healing ${ }^{16}$. In this study for the evaluation of the mucosal healing capsule endoscopy was used.

In our study, we noticed a significant correlation between platelet count and the other inflammatory biomarkers that are routinely used to assess the disease severity of Crohn's disease patients, like C-reactive protein and fecal calprotectin and hemoglobin value. Thrombocytosis was present at most patients that associated elevated CRP, fecal calprotectin more than 250microg/g and anemic syndrome.

Several studies support the role of platelets in the inflammatory cascade of chronic inflammatory diseases. Many platelet changes has been described in IBD, including morphological and functional alteration and increased number ${ }^{6}$. Platelets act as inflammatory amplifiers, releasing proinflammatory substances and expressing inflammatory receptors, an increased platelet count indicating an inflammatory active process ${ }^{2,13}$. A study with IBD Chinese population reported that by adding monitoring platelet count to fecal biomarkers (like fecal calprotectin and fecal immunochemical test), the specificity in detecting endoscopically active IBD improved from $87.5 \%$ to $>94 \%{ }^{18}$.
Anemia, iron deficiency and thrombocytosis are common complications in IBD patients. In our group we noticed that most patients with anemia $(54.84 \%$ of all the patients) associated thrombocytosis and only 3 patients (4.84\% of all the patients) with normal hemoglobin values associated thrombocytosis. There are several studies, including the one conducted by Voudoukis et al., that prove a causality relationship between thrombocytosis and anemia and, similar to our study, the level of platelet count correlates with iron deficiency anemia and disease severity ${ }^{19}$. The same study shows that managing the inflammation and iron deficiency is associated with a normalization of platelet count ${ }^{19}$.

In this study, we analyzed the association between thrombocytosis and endoscopic activity of Crohnls disease evaluated with capsule endoscopy and examine the potential role of this factor as an inflammatory biomarker in CD .

We had six complications, three due to capsule malfunction which were replaced, one asymptomatic delay in eliminating capsule for more than 24 hours and two capsule retention due to Crohn's disease stenosis. Using patency capsule prior to the investigation could be a method for reducing the risk of capsule retention but due to the expensive costs, in the studied population patency capsule was not administrated.

\section{CONCLUSION}

To our knowledge, this is the first study that assesses the correlation between thrombocytosis and Crohn's disease endoscopic severity evaluated with capsule endoscopy. Our data suggests that platelet count is a valuable, non-invasive, easy to use biomarker that is a good predictor of severity of Crohn's disease and could have a prognostic value. It correlates well with Lewis score, CRP, fecal calprotectin and anemia. Platelet count could be integrated in close monitoring of Crohn's disease patients in a "treat to target” approach, along with the other inflammatory biomarkers, evaluating endoscopic and clinical activity and the quality of life. Also, platelet count is a valuable parameter that could positively influence the diagnostic yield of capsule endoscopy, corroborated with other clinical and biological parameters.

Compliance with ethics requirements: The authors declare no conflict of interest regarding this article. The authors declare that all the procedures and experiments of this study respect the ethical standards in the 
Helsinki Declaration of 1975, as revised in 2008(5), as well as the national law. Informed consent was obtained from all the patients included in the study.

\section{References}

1. Molodecky NA, Soon IS, Rabi DM, Ghali WA, Ferris M, Chernoff G, et al. Increasing Incidence and Prevalence of the Inflammatory Bowel Diseases With Time, Based on Systematic Review. Gastroenterology [Internet]. 2012 Jan 1;142(1):46-54.e42. Available from: https://doi.org/10.1053/j.gastro.2011.10.001

2. Freeman $\mathrm{K}$, Ryan $\mathrm{R}$, Parsons $\mathrm{N}$, Taylor-Phillips $\mathrm{S}$, Willis $\mathrm{BH}$, Clarke A. The incidence and prevalence of inflammatory bowel disease in UK primary care: a retrospective cohort study of the IQVIA Medical Research Database. BMC Gastroenterol [Internet]. 2021;21(1):139. Available from: https://doi.org/10.1186/s12876$021-01716-6$

3. Le Berre C, Trang-Poisson C, Bourreille A. Small bowel capsule endoscopy and treat-to-target in Crohn's disease: A systematic review. World J Gastroenterol [Internet]. 2019 Aug 21;25(31):4534-54. Available from: https://pubmed.ncbi.nlm.nih. gov/31496630

4. Mosli MH, Zou G, Garg SK, Feagan SG, MacDonald JK, Chande N, et al. C-Reactive Protein, Fecal Calprotectin, and Stool Lactoferrin for Detection of Endoscopic Activity in Symptomatic Inflammatory Bowel Disease Patients: A Systematic Review and Meta-Analysis. Off J Am Coll Gastroenterol | ACG [Internet]. 2015;110(6). Available from:https://journals.Iww.com/ajg/Fulltext/2015/06000/C_ Reactive_Protein,_Fecal_Calprotectin,_and_Stool.10.aspx

5. D'Haens G, Ferrante M, Vermeire S, Baert F, Noman M, Moortgat $L$, et al. Fecal Calprotectin is a Surrogate Marker for Endoscopic Lesions in Inflammatory Bowel Disease. Inflamm Bowel Dis [Internet]. 2012 Dec 1;18(12):2218-24. Available from: https://doi. org/10.1002/ibd.22917

6. Voudoukis E, Karmiris K, Koutroubakis IE. Multipotent role of platelets in inflammatory bowel diseases: a clinical approach. World J Gastroenterol [Internet]. 2014 Mar 28;20(12):3180-90. Available from: https://pubmed.ncbi.nIm.nih.gov/24696603

7. Who, Chan M. Haemoglobin concentrations for the diagnosis of anaemia and assessment of severity. Geneva, Switz World Heal Organ [Internet]. 2011;1-6. Available from: http://scholar.google. $\mathrm{com} /$ scholar?hl=en\&btnG =Search\&q=intitle:Haemoglobin + concentrations+for+the+diagnosis+of+anaemia+and+assessment+of+severity\# 1

8. MOROWITZ DA, ALLEN LW, KIRSNER JB. Thrombocytosis in Chronic Inflammatory Bowel Disease. Ann Intern Med [Internet]. 1968 May 1;68(5):1013-21. Available from: https://www.acpjournals.org/doi/abs/10.7326/0003-4819-68-5-1013

9. Li L, Xu P, Zhang Z, Zhou X, Chen C, Lu C. Platelets can reflect the severity of Crohn's disease without the effect of anemia. Clinics (Sao Paulo) [Internet]. 2020/07/10. 2020;75:e1596-e1596. Available from: https://pubmed.ncbi.nlm.nih.gov/32667493

10. Holmquist L, Åhren C, Fällström SP. Relationship Between Results of Laboratory Tests and Inflammatory Activity Assessed by Colonoscopy in Children and Adolescents with Ulcerative Colitis and Crohn's Colitis. J Pediatr Gastroenterol Nutr [Internet]. 1989;9(2). Available from: https://journals.Iww.com/ jpgn/Fulltext/1989/08000/Relationship_Between_Results_of_ Laboratory_Tests.10.aspx
11. Okon A, Dubinsky M, Vasiliauskas EA, Papadakis KA, Ippoliti A, Targan SR FP. Elevated platelet count before ileal pouch-anal anastomosis for ulcerative colitis is associated with the development of chronic pouchitis. Am Surg. 2005;Oct;(71(10))::821-6.

12. Lian L, Fazio VW, Lavery IC, Hammel J, Remzi FH, Shen B. Evaluation of Association Between Precolectomy Thrombocytosis and the Occurrence of Inflammatory Pouch Disorders. Dis Colon Rectum [Internet]. 2009;52(11). Available from: https://journals.Iww.com/dcrjournal/Fulltext/2009/11000/Evaluation_of_ Association_Between_Precolectomy.16.aspx

13. CHOW DKL, SUNG JJY, TSOI KKF, WONG VWS, WU JCY, LEONG RWL, et al. Predictors of corticosteroid-dependent and corticosteroid-refractory inflammatory bowel disease: analysis of a Chinese cohort study. Aliment Pharmacol Ther [Internet]. 2009 Apr 1;29(8):843-54. Available from: https://doi. org/10.1111/j.1365-2036.2009.03944.x

14. Ríos JWH, Jordá FC, Benaprés JRM. Predictive factors of poor response to intravenous cyclosporine in steroid-refractory ulcerative colitis. 2009;163-71.

15. Thapa SD, Hadid H, Imam W, Hassan A, Usman M, Jafri S-M, et al. Persistent Reactive Thrombocytosis May Increase the Risk of Coronary Artery Disease Among Inflammatory Bowel Disease Patients. Dig Dis Sci [Internet]. 2015;60(10):3062-8. Available from: https://doi.org/10.1007/s10620-015-3701-1

16. Macedo Silva V, Freitas M, Boal Carvalho P, Dias de Castro F, Cúrdia Gonçalves T, Rosa B, et al. Apex Score: Predicting Flares in Small-Bowel Crohn's Disease After Mucosal Healing. Dig Dis Sci [Internet]. 2021; Available from: https://doi.org/10.1007/ s10620-021-07148-2

17. Danese S, De La Motte C, Fiocchi C. Platelets in inflammatory bowel disease: Clinical, pathogenic, and therapeutic implications. Am J Gastroenterol. 2004;99(5):938-45.

18. Mak L-Y, Tong TSM, Cheung K-S, Chen L-J, Lui K-L, Lau K-S, et al. Combined Use of Common Fecal and Blood Markers for Detection of Endoscopically Active Inflammatory Bowel Disease. Clin Transl Gastroenterol [Internet]. 2020;11(3). Available from: https://journals.Iww.com/ctg/Fulltext/2020/03000/Combined_ Use_of_Common_Fecal_and_Blood_Markers_for.1.aspx

19. Voudoukis, E., Karmiris, K., Oustamanolakis, P., Theodoropoulou, A., Sfiridaki, A., Paspatis, G. A., \& Koutroubakis IE. Association between thrombocytosis and iron deficiency anemia in inflammatory bowel disease. Eur J Gastroenterol Hepatol.2013;25(10), 1212-1216. 